\title{
Foot length measurements of newborns of high and low risk pregnancies*
}

\author{
Medida do comprimento hálux-calcâneo de recém-nascidos \\ em gestações de alto e baixo risco \\ Medida de longitud hallux-calcáneo de recién nacidos en \\ gestaciones de alto y bajo riesgo
}

Ana Karina Marques Salge ${ }^{1}$, Érika Lopes Rocha ${ }^{2}$, Maria Aparecida Munhoz Gaíva ${ }^{3}$, Thaíla Correa Castral', Janaína Valadares Guimarães ${ }^{1}$, Raphaela Maioni Xavier ${ }^{2}$

How to cite this article:

Salge AKM, Rocha EL, Gaíva MAM, Castral TC, Guimarães JV, Xavier RM. Foot length measurements of newborns of high and low risk pregnancies. Rev Esc Enferm USP. 2017;51:e03200. DOI: http://dx.doi.org/10.1590/S1980-220X2016016703200

* Extracted from the dissertation "Utilização do método Hálux-Calcâneo na identificação de desvios de crescimento em recém-nascidos", Universidade Federal de Goiás, 2013.

${ }^{1}$ Universidade Federal de Goiás, Faculdade de Enfermagem, Goiânia, GO, Brazil.

${ }^{2}$ Universidade Federal de Goiás, Programa de Pós-Graduação em Enfermagem, Goiânia, GO, Brazil.

${ }^{3}$ Universidade Federal do Mato Grosso,

Programa de Pós-Graduação em

Enfermagem, Cuiabá, MT, Brazil.

\begin{abstract}
Objective: Comparing foot length measurements of newborns in high and low risk pregnancies at a public hospital in Goiânia, GO, Brazil. Method: A cross-sectional study carried out between April, 2013 and May, 2015, with a sample consisting of 180 newborns; 106 infants of women from high-risk pregnancies and 74 of women from low-risk pregnancies. Data were descriptively analyzed. Foot length measurement was performed using a stiff transparent plastic ruler, graduated in millimeters. The length of both feet was measured from the tip of the hallux (big toe) to the end of the heel. Results: A statistically significant relationship was found between the foot length and newborn's weight, between the cephalic and thoracic perimeters in the high-risk group and between the cephalic perimeter in the control group. Conclusion: There is a need for creating cut-off points to identify newborns with intrauterine growth disorders using foot length.
\end{abstract}

DESCRIPTORS

Infant Newborn; Gestacional Age; Pregnancy, High-Risk; Infant, Low Birth Weight; Maternal-Child Nursing. 


\section{INTRODUCTION}

When the growth potential of the fetus suffers any interference in high-risk pregnancies, anthropometric measures are one of the first signs that can alert professionals to the presence of an adverse situation. In addition, some neonatal clinical conditions including premature birth and low birth weight are directly associated with the occurrence of high-risk pregnancies where neonatal mortality is the main consequence $e^{(1-3)}$.

Gestational age (GA) and newborn (NB) weight at birth are described in the literature as essential for evaluating the pattern of intrauterine growth and development, to predict the difficulties of extrauterine adaptation, diseases in the neonatal period and to estimate the risk of (neonatal) death ${ }^{(3-4)}$.

In this sense, in searching for simple and reliable methods that may help in distinguishing between the narrow biological variability of the fetuses, studies have used foot length (hallux-calcaneus length - HCL) to estimate gestational age with greater precision ${ }^{(5-10)}$.

HCL is a quantifiable easy-to-apply morphometric parameter, and because it contains only one variable to be measured, it is less susceptible to misinterpretation ${ }^{(11-12)}$.

HCL can be measured using equipment specifically developed for this purpose, or simply using a non-elastic tape or a graduated ruler ${ }^{(13)}$. Usually the centimeters between the center of the heel to the tip of the hallux are measured ${ }^{(10)}$.

There is a clear need for a rapid and effective method to determine GA and birth weight which can be used in newborns with diseases, preterm/premature infants or those living in areas of poverty and communities with difficult access, since these groups present greater difficulties in evaluating these parameters ${ }^{(10)}$. It is hypothesized that the HCL measurement could be a good parameter for newborn clinical evaluation, especially in cases of high-risk pregnancy. In this perspective, the present investigation is justified by offering knowledge about the importance of the HCL method to subsidize systematization and reorientation of safe care to newborns.

Considering that despite the advantages of this method, it is still little used in our reality, so the objective of this study was to compare foot length (HCL) measurements in newborns of high and low risk pregnancies in a public hospital in Goiânia, GO, Brazil.

\section{METHOD}

This is a cross-sectional study developed in the maternity ward of a public federal hospital, a part of the (Brazilian) Unified Healthcare System (SUS) of Goiânia, Goiás, Brazil, from April, 2013 to May, 2015.

The sample consisted of 180 newborns born between April, 2013 and May, 2015, and met the inclusion criteria; of which 106 were children of high-risk pregnancy women with the clinical diagnoses of Hypertensive Disorders of Pregnancy (HDP) and Diabetes Mellitus (DM), and 74 newborns born to women of low-risk pregnancy (control group).
The study included live newborns of up to 24 hours of life whose mothers showed the clinical criteria for classification as a high-risk pregnancy, among them: Hypertensive Disorders of Pregnancy (HDP), Gestational Diabetes (GD) and Diabetes Mellitus type I and II (DM1 or DM2), in addition to having medical records available for data collection and with complete information containing birth weight and gestational age. As HCL increases significantly during the first five days of extrauterine life ${ }^{(7)}$, we chose to perform the measurements within the first 24 hours after birth as recommended by the literature, and each newborn had the HCL measured only once. Newborns with congenital malformations in the lower limbs were excluded from the study.

HCL was measured by one of the researchers on both feet of the newborn using a transparent and stiff plastic $30-\mathrm{cm}$ ruler graduated in millimeters, and adopting the length of the tip of the hallux to the end of the heel ${ }^{(8-12)}$.

Mothers' and newborns' clinical data were obtained from the medical records of each patient through the institution's own forms/files containing the following items: maternal and fetal underlying diseases; gestational age (determined by the date of the last menstruation, the ultrasound performed in the first trimester and by the Capurro method); obstetric history; possible maternal obstetric and fetal/neonatal complications; neonatal anthropometric measures (birth weight, cephalic and thoracic perimeters); and Apgar score in the $1^{\text {st }}$ and $5^{\text {th }}$ minutes.

Quantitative data such as mean gestational age and anthropometric measurements were descriptively analyzed by frequency distribution, means, and standard deviation. Proportions such as the relationship between weight, cephalic perimeter, thoracic perimeter and Apgar score with the newborn's HCL from the mothers in the control group and those from high-risk pregnancies were compared by the $\chi^{2}$ test, followed by the Fisher's exact test or Yates correction test. Statistically significant differences were observed in which the $\mathrm{p}$ value was lower than $5 \%(p<0.05)$.

The study development complied with national and international standards of research ethics involving human subjects. The results presented here are part of the matrix project "Avaliação da resposta imunológica materna e fetal em gestantes com doença hipertensiva" (Evaluation of the maternal and fetal immune response in pregnant women with hypertensive disease), and approved by the Ethics Committee on Human and Animal Medical Research of the Hospital das Clinicas of the Federal University of Goiás, under opinion number 101/2008. The women who met the inclusion criteria established for this study were clarified as to the purpose of the investigation and the nature of the data collection, and those who agreed to participate signed the Free and Informed Consent Form (TCLE).

\section{RESULTS}

The mean GA of small NB for gestational age (SGA) in the control group was $278.8 \pm 5.1$ days, and for the highrisk pregnancy group it was $259 \pm 15.9$ days. A statistically significant relationship was found between gestational age and small newborns for gestational age (SGA) in the 
control group (0.002), and in the high-risk pregnancy group (0.001). SGA newborns predominated in both groups, with
$60.9 \%$ in the control group and $49 \%$ in the high-risk pregnancy group (Table 1).

Table 1 - Distribution of newborns (NB) of women in high-risk pregnancies and control group, according to birth weight classification in a public federal maternity hospital - Goiânia, GO, Brazil, 2013-2015.

\begin{tabular}{cccccccc}
\hline & \multicolumn{3}{c}{ NB control group } & \multicolumn{3}{c}{ NB high-risk pregnancy group } \\
\hline NB & $\mathbf{n}(\%)$ & GA in days (mean \pm SD) & $p$-value & NB & n (\%) & GA (mean \pm SD) & $p$-value \\
\hline AGA & $22(29.7)$ & $264.4 \pm 2.2$ & 0.008 & AGA & $35(33)$ & $264.2 \pm 14.4$ & 0.086 \\
SGA & $45(60.9)$ & $278.8 \pm 5.1$ & $\mathbf{0 . 0 0 2 *}$ & SGA & $52(49)$ & $259 \pm 15.9$ & $\mathbf{0 . 0 0 1 *}$ \\
LGA & $7(9.4)$ & $288.6 \pm 3.7$ & 0.762 & LGA & $19(18)$ & $270.9 \pm 14.4$ & 0.026 \\
\hline Total & $74(100)$ & $277.3 \pm 1.8$ & & Total & $106(100)$ & $264.4 \pm 5.5$
\end{tabular}

AGA: Adequate for gestational age; LGA: Large for gestational age; SGA: Small for gestational age; GA: gestational age; SD: standard deviation; n: number of cases; $p$-value: Chi-square or Fisher's exact test.

Table 2 describes the relationship between weight, cephalic perimeter $(\mathrm{CP})$, thoracic perimeter $(\mathrm{TP})$ and Apgar score with HCL in infants born to mothers in the control group and for mothers of high-risk pregnancies. Newborns with SGA had the lowest HCL measurements, with a statistically significant relationship between the HCL of newborns with SGA in the control group $(p=0.004)$ and in the high-risk pregnancy group $(p=0.003)$.

Table 2 - Relationship between foot length $(\mathrm{HCL})$ and the neonatal variables in newborns of high-risk pregnancies and of mothers in the control group in a public federal maternity hospital - Goiânia, GO, Brazil, 2013-2015.

\begin{tabular}{ccccccccc}
\hline \multirow{2}{*}{$\begin{array}{c}\text { Neonatal } \\
\text { variables }\end{array}$} & \multicolumn{4}{c}{$\begin{array}{c}\text { Control group } \\
\text { Mean } \pm \text { SD }\end{array}$} \\
\cline { 2 - 10 } & SGA & LGA & AGA** & $p$-value & SGA & LGA & AGA & $p$-value \\
\hline Weight & $2466 \pm 365.1$ & $4410 \pm 355.3$ & $3008.6 \pm 698.1$ & 0.0152 & $2126.9 \pm 411.49$ & $3987.2 \pm 345.3$ & $3030.8 \pm 473.6$ & 0.0035 \\
\hline CP & $32.7 \pm 2.28$ & $36.9 \pm 0.36$ & $34.5 \pm 6.67$ & 0.0435 & $31.88 \pm 1.92$ & $35.59 \pm 1.22$ & $33.97 \pm 2.09$ & 0.0156 \\
TP & $30.8 \pm 2.17$ & $36 \pm 1.00$ & $33 \pm 3.17$ & 0.0615 & $29.54 \pm 2.81$ & $35.09 \pm 0.94$ & $32.34 \pm 2.63$ & 0.0298 \\
\hline Apgar at 1 min & $9 \pm 1.00$ & $7.33 \pm 1.15$ & $7.88 \pm 1.95$ & 0.1600 & $6.85 \pm 1.62$ & $8.27 \pm 0.79$ & $7.53 \pm 1.67$ & 0.0374 \\
Apgar at $\mathbf{5}$ min & $9.60 \pm 0.55$ & $9.33 \pm 0.58$ & $9.42 \pm 0.66$ & 0.1570 & $9.08 \pm 0.76$ & $9.64 \pm 0.50$ & $9.12 \pm 0.63$ & 0.2410 \\
\hline HCL & $7.23^{*} \pm 0.07$ & $9.35 \pm 0.16$ & $7.56 \pm 0.002$ & $\mathbf{0 . 0 0 4 *}$ & $7.56^{*} \pm 0.05$ & $7.99 \pm 0.07$ & $7.870 .03 \pm$ & $\mathbf{0 . 0 0 3 *}$ \\
\hline
\end{tabular}

SD: standard deviation; SGA: Small for gestational age; LGA: Large for gestational age; AGA: Adequate for gestational age; SD: standard deviation; n: number of cases; p-value: Chi-square or Fisher's exact test; CP: Cephalic perimeter; TP: Thoracic perimeter

\section{DISCUSSION}

Foot length assessment is an important element for the fetal structural screening at all gestational ages. As it is a linear body measure, it can be closely related to gestational age, weight, length and perimeters ${ }^{(6,9-10)}$.

Weight is the most frequently associated measure of growth. Birth weight establishes whether a child is small, large, or adequate for gestational age ${ }^{(10)}$. An accurate assessment of growth in the neonatal period is very important and allows insight into whether the fetus was subjected to abnormal intrauterine conditions that resulted in delayed or accelerated growth ${ }^{(12)}$.

A statistically significant relationship was found between gestational age and infants with SGA in the control group and in the high-risk pregnancy group, and between the HCL of SGA newborns in the control group and in the high-risk pregnancy group. Several studies have also shown a strong correlation between foot length growth and birth weight $^{(7-9,13-14)}$. According to the literature, the HCL value suggested for adequate fetal growth would be 7.1 to $7.3 \mathrm{~cm}$ for SGA infants, 7.5 to $7.7 \mathrm{~cm}$ for AGA infants, and from 7.8 to $7.9 \mathrm{~cm}$ for LGA infants ${ }^{(13)}$.

SGA infants from control group had a mean HCL of $7.23 \mathrm{~cm}$, similar to that described in three other studies which observed control groups values of $7.13 \mathrm{~cm}^{(15)}, 7.24$ $\mathrm{cm}^{(13)}$ and $7.20 \mathrm{~cm}^{(9)}$.

Regarding AGA infants, the mean HCL of the control group was $7.56 \mathrm{~cm}$ and $7.87 \mathrm{~cm}$ for the high-risk group, similar values to those found in other studies of $7.6 \mathrm{~cm}^{(15)}$, $7.8 \mathrm{~cm}^{(8)}$ and $7.92 \mathrm{~cm}^{(13)}$. It may be noted that all cut-off points for AGA were equal to or greater than the cut-off points for SGA.

The prevalence of newborns with low birth weight (LBW) was very similar in both groups. Of the total sample, $14.63 \%$ of the newborns in the control group and $15.91 \%$ of newborns in the high-risk group weighed less than $2,500 \mathrm{~g}$. It is estimated that between $15 \%$ and $20 \%$ of all births in the world are $\mathrm{LBW}^{(16)}$. In Brazil, the percentage of infant births with low birth weight has increased slightly from $7.7 \%$ in 
2000 to $8.5 \%$ in $2011^{(16)}$. In a hospital-based recruitment conducted in Tanzania, a 15\% prevalence of LBW infants was identified ${ }^{(17)}$. On the other hand, a study developed in Uganda showed a slightly lower percentage of LBW, being $12 \%{ }^{(7)}$. Two studies conducted in Nepal, where $95 \%$ of births are homebirths and $75 \%$ of the population live below the poverty line, discrepant percentages of LBW were identified: $28.6 \%{ }^{(18)}$ prevalence in the first study; and more recently of $6.7 \%$ prevalence in the second study ${ }^{(10)}$.

The ideal maximum period to perform HCL measurement is still controversial. Some authors state that HCL maintains a strong correlation with weight from birth up to the fifth day after birth, being a good predictor for the evaluation of low birth weight ${ }^{(16-18)}$. However, a study revealed that newborn's feet significantly increase in length/size during the first five days of life, suggesting that further research needs to be developed to determine the maximum period for this measure ${ }^{(7)}$. HCL of infants adequate for gestational age was $7.56 \mathrm{~cm}$ in the control group and $7.87 \mathrm{~cm}$ in the high-risk group. According to the literature, HCL of newborns with adequate weight may range from $7.40 \mathrm{~cm}$ to $7.99 \mathrm{~cm}^{(7)}$.

Regarding the Apgar data in the first minute, the highrisk group obtained a higher number of newborns with averages lower than eight in comparison to infants from the control group. Regarding the relationship between HCL and Apgar, this was only significant in the first minute for the high-risk pregnancy group, and did not present a strong correlation with the other newborns. There are reports in the literature of an association between low values of the Apgar score in the first and fifth minutes and congenital orthopedic problems, and not directly related to the HCL measurement ${ }^{(19)}$. No studies were found that directly related HCL to cephalic and thoracic perimeters values, and Apgar indexes.

It is observed that HCL is routinely used in pediatric and forensic necropsies in order to establish GA in fetuses and stillbirths. Although not used in neonatal nursing care, HCL along with other criteria for clinically evaluating newborns (such as weight, Apgar score, cephalic, thoracic and abdominal circumferences) can positively contribute to a more overall analysis of a newborn's conditions at birth, their ability to adapt to extrauterine life and to measure $\mathrm{GA}^{(20)}$.

Considering that $\mathrm{HCL}$ is easy to apply since it has only one variable to be measured and is therefore less susceptible to errors, and that the material used for the measurement is easily found in any maternity or health service, this morphometric parameter should be more used by professionals such as nurses, pediatricians/neonatologists, members of the nursing team and pathologists who work in maternity and child areas.

This study presents some limitations for being a prospective study and for using data from medical records in which there was no standardization of the records, the information was often written down in an incomplete or inadequate manner and in illegible handwriting, and often did not contain records of the nursing team. Thus, a large amount of information is missing in this type of study.

\section{CONCLUSION}

A statistically significant relationship was found between HCL and weight at birth in SGA, LGA and AGA infants of all gestational ages in both groups, as well as between $\mathrm{HCL}$ and $\mathrm{CP}$ and TP in the high-risk group, and between the $\mathrm{HCL}$ and $\mathrm{CP}$ in the control group.

The heterogeneity of the results points to the need to establish cutoff points to identify newborns with possible alterations/disorders in low and high-risk pregnancies, as well as to define the mean HCL that is to be accepted as normal for the neonatal population, so that this parameter can be used as a reliable instrument for measuring GA in newborns.

Weight, cephalocaudal length and perimeters are commonly evaluated during the anthropometric evaluation of newborns. However, the combined use of anthropometric measures that compare two or more aspects of growth may provide more consistent information regarding the risk of morbidity. For this reason, the HCL measurement may aid in the anthropometric evaluation of newborns and provide a more comprehensive view on the quality of fetal and neonatal growth and development.

\section{RESUMO}

Objetivo: Comparar as medidas do comprimento hálux-calcâneo de recém-nascidos em gestações de alto e baixo risco em um hospital público de Goiânia, GO. Método: Estudo transversal, realizado no período de abril de 2013 a maio de 2015, cuja amostra constituiu-se de 180 recém-nascidos, 106 filhos de mulheres com gestação de alto risco e 74 de mulheres com gestação de baixo risco. Os dados foram analisados descritivamente. A medida do comprimento hálux-calcâneo foi realizada utilizando-se de régua plástica transparente rígida, graduada em milímetros. Foram medidos ambos os pés, aferindo-se o comprimento da ponta do hálux até a extremidade do calcâneo. Resultados: Foi encontrada relação estatisticamente significante entre o comprimento hálux-calcâneo e o peso do recém-nascido, entre os perímetros cefálico e torácico no grupo de alto risco e entre o perímetro cefálico no grupo controle. Conclusão: Existe necessidade da criação de pontos de corte para identificar recém-nascidos com desvios de crescimento intrauterino utilizando-se do comprimento hálux-calcâneo.

\section{DESCRITORES}

Recém-Nascido; Idade Gestacional; Gravidez de Alto Risco; Recém-Nascido de Baixo Peso; Enfermagem Materno-Infantil.

\section{RESUMEN}

Objetivo: Comparar las mediciones de la longitud hallux-calcáneo de los recién nacidos en embarazos de alto y bajo riesgo en un hospital público de Goiânia, GO. Método: Estudio transversal realizado de abril 2013 a mayo 2015, cuya muestra estuvo constituida por 180 recién nacidos, 106 de mujeres con embarazos de alto riesgo y 74 de mujeres con embarazos de bajo riesgo. Los datos se analizaron 
de manera descriptiva. La medida de la longitud hallux-calcáneo se realizó mediante regla de plástico rígido transparente, graduada en milímetros. Se midieron en ambos pies, las longitudes de la punta del hallux hasta el final del calcáneo. Resultados: Se encontró una relación estadísticamente significativa entre la longitud hallux-calcáneo y el peso del recién nacido, entre las circunferencias cefálica y torácica en el grupo de alto riesgo y entre la circunferencia cefálica en el grupo control. Conclusión: Existe la necesidad de crear puntos de corte para identificar los recién nacidos con desviaciones de crecimiento intrauterino utilizando la longitud desde el hallux hasta el calcáneo.

\section{DESCRIPTORES}

Recién Nacido; Edad Gestacional; Embarazo de Alto Riesgo; Recién Nacido de Bajo Peso; Enfermería Maternoinfantil.

\section{REFERENCES}

1. Hirst JE, Ha LT, Jeffery HE. The use of fetal foot length to determine stillborn gestational age in Vietnam. Int J Gynaecol Obstet. $2012 ; 116(1): 22-5$.

2. Dekker GA. Management of preeclampsia. Pregnancy Hypertens. 2014;4(3):246-47.

3. Koullali B, Oudijk MA, Nijman TA, Mol BW, Pajkrt E. Risk assessment and management to prevent preterm birth. Semin Fetal Neonatal Med. 2016;21(2):80-8.

4. Juárez SP. Notes on vital statistics for the study of perinatal health. Gac Sanit. 2014;28(6):505-07.

5. Feresu SA, Wang Y, Dickinson S. Relationship between maternal obesity and prenatal, metabolic syndrome, obstetrical and perinatal complications of pregnancy in Indiana, 2008-2010. BMC Pregnancy Childbirth. 2015;15:266.

6. Mukherjee S, Roy P, Mitra S, Samanta M, Chatterjee S. Measuring new born foot length to identify small babies in need of extra care: a cross-sectional hospital based study. Iran J Pediatr. 2013;23(5):508-12.

7. Nabiwemba E, Marchant T, Namazzi G, Kadobera D, Waiswa P. Identifying high-risk babies born in the community using foot length measurement at birth in Uganda. Child Care Health Dev. 2013;39(1):20-6.

8. Marchant T, Penfold S, Mkumbo E, Shamba D, Jaribu J, Manzi F, et al. The reliability of a newborn foot length measurement tool used by community volunteers to identify low birth weight or premature babies born at home in southern Tanzania. BMC Public Health. 2014;14:859-63.

9. Ashish KC, Nelin V, Vitrakoti R, Aryal S, Målqvist M. Validation of the foot length measure as an alternative tool to identify low birth weight and preterm babies in a low-resource setting like Nepal: a cross-sectional study. BMC Pediatr. 2015;15:43.

10. Wyk LV, Smith J. Postnatal foot length to determine gestational age: a pilot study. J. Trop Pediatr. 2016;62(2):144-51.

11. Elizabeth NL, Christopher OG, Patrick K. Determining an anthropometric surrogate measure for identifying low birth weight babies in Uganda: a hospital-based cross sectional study. BMC Pediatr. 2013;13:54.

12. Thawani R, Dewan P, Faridi MM, Arora SK, Kumar R. Estimation of gestational age, using neonatal anthropometry: a cross-sectional study in India. J Health Popul Nutr. 2013;31(4):523-30.

13. James DK, Dryburgh EH, Chiswick ML. Foot length-a new and potentially useful measurement in the neonate. Arch Dis Child. 1979;54(3):226-30.

14. Das S, Bapat U, More NS, Alcock G, Fernandez A, Osrin D. Nutritional status of young children in Mumbai slums: a follow-up anthropometric study. Nutr J. 2012;11:100.

15. Gohil JR, Sosi M, Vani SN, Desai AB. Footlength measurement in the neonate. Indian J Pediatr. 1991;58(5):675-77.

16. United Nations Children's Fund (UNICEF). Committing to Child Survival: a Promise Renewed. Progress Report [Internet]. New York: UNICEF; 2014 [cited 2016 Jan 25]. Available from: http://www.apromiserenewed.org/APR_2014_web_15Sept14.pdf

17. Marchant T, Jaribu J, Penfold S, Tanner M, Schellenberg JA. Measuring newborn foot length to identify small babies in need of extra care: a cross sectional hospital based study with community follow-up in Tanzania. BMC Public Health. 2010;10:624.

18. Mullany LC, Darmstadt GL, Khatry SK, Leclerq SC, Tielsch JM. Relationship between the surrogate anthropometric measures, foot length and chest circumference and birth weight among newborns of Sarlahi, Nepal. Eur J Clin Nutr. 2007;61(1):40-6.

19. Chotigavanichaya C, Leurmsumran P, Eamsobhana P, Sanpakit $S$, Kaewpornsawan K. The incidence of common orthopaedic problems in newborn at Siriraj Hospital. J Med Assoc Thai. 2012;95(9):S54-61.

20. Zago AFR, Paravidine LM, Siqueira LMS, Balbão LM, Reis MA, Castro ECC. Estudo comparativo entre o comprimento hálux-calcâneo e outros métodos de avaliação de idade gestacional em recém-nascidos. Pediatr Mod. 2000;36(6):388-91. 